\title{
Research Paper \\ The Effect of Interval Training and Consuming Fenugreek Seed Extract on FGF- 21 and VEGF Gene Expression in Patients With Coronary Artery Diseases
}

\author{
Ebad Roohbakhsh ${ }^{1}$ (), "Alireza Barari ${ }^{1}$ 이, Hajar Abbaszadeh²
}

1. Department of Sport Physiology, Ayatollah Amoli Branch, Islamic Azad University, Amol, Iran.

2. Department of Sport Physiology, Sari Branch, Islamic Azad University, Sari, Iran.

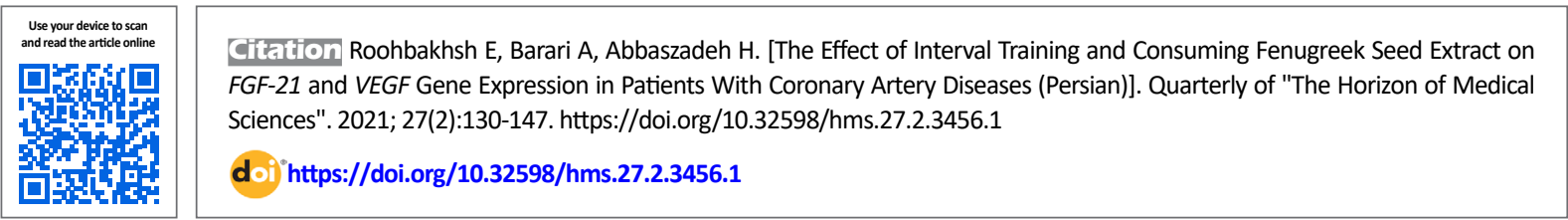

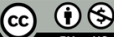

Received: 16 Sep 2020 Accepted: 31 Oct 2020 Available Online: 01 Apr 2021

Keywords: Interval training Fenugreek, Fibroblast Growth Factor (FGF21), Vascular Endothelial Growth Factor (VEGF), Coronary artery disease

\section{A B STRACT}

Aims A high-fat diet, smoking, and a sedentary lifestyle are the major causes of Coronary Artery Disease (CAD). This study aimed to explore the effect of interval training and the consumption of fenugreek seed extract on FGF-21 and VEGF gene expression among patients with CAD.

Methods \& Materials The present quasi-experimental study was conducted on a sample of 32 male patients with CAD, aged between 55 and 65 years. They were randomly divided into four groups: control, training only, fenugreek only, and training + fenugreek. The training program consisted of eight weeks of interval running, three sessions per week with an intensity of $55 \%$ and $65 \%$ of heart rate reserve, with a gradually increasing intensity. Subjects consumed $10 \mathrm{mg} / \mathrm{kg}$ of fenugreek extract daily. Real-time PCR was used to measure the expression of FGF-21 and VEGF genes.

Findings The results showed that the mean expression ratios of FGF-21 in training only, fenugreek only, and training + fenugreek groups were significantly higher than the control group $(P<0.0001)$. The fenugreek + training group had a greater significant increase $(P<0.0001)$ more than the training + fenugreek group. Moreover, the mean Coefficient of Variation (CV) of VEGF gene expression was significantly increased more than that in the training group $(P<0.0001)$, fenugreek group $(P=0.0004)$, and the training + fenugreek group $(P<0.0001)$, compared to the control group. The fenugreek + training group had a greater and more significant increase than the training only $(P=0.0181)$ and the fenugreek only groups $(P<0.0495)$. Conclusion The results showed that a combination of interval training and consumption of fenugreek seed extract increased the CV of FGF-21 and VEGF gene expression and thus, have beneficial effects on the angiogenesis pathway in patients with CADs.

\section{English Version}

\section{Introduction}

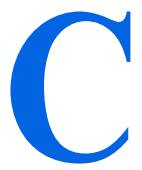

oronary Artery Disease (CAD) has prevailed the world more than any other disease and has accounted for many disabilities and mortalities. Among the main factors contributing to this disease are a high-fat diet, smoking, and an inactive life- style [1]. Many financial and life-threatening costs accompany the treatment and rehabilitation of this disease. Thus, it is essential to prevent its underlying factors. Prevention of the disease is deemed possible through controlling the risk factors of cardiovascular diseases such as hypertension, blood fats (lipids), a high percentage of body lipids, and avoiding sedentary life (doing exercise) [2].

Physical training makes the body adaptive and can, thus, reduce the mortality rate of cardiovascular diseases and

\section{${ }^{*}$ Corresponding Author:}

\section{Alireza Barari, PhD.}

Address: Department of Sport Physiology, Faculty of Physical Education, Ayatollah Amoli Branch, Islamic Azad University, Amol, Iran.

Tel: +98 (911) 1277793

E-mail: alireza54.barari@gmail.com 
helps improve cardiovascular functioning. One such adaptation is the angiogenesis procedure. A variety of growth factors are involved in this procedure, the most important of which are the Fibroblast Growth Factor (FGF) and the Vascular Endothelial Growth Factor (VEGF) [3, 4]. The latter is the most potent mitogen specific to the endothelial cells [5], known as a critical regulator of angiogenesis [4]. These vascular endothelial growth factors perform their biological function by acting on the receptor tyrosine kinases in the plasma membrane of the target cells. After linking to their ligand, these receptors turn into a dimer and are auto-phosphorylated, which finally ends in intracellular cascade events. $V E G F$ is secreted in response to stimulants such as hypoxia and shear stress (the homodynamic force originating from the friction of blood flow and artery walls) from the endothelial cells [5]. Some research on the VEGF gene expression in human skeletal muscle showed a simultaneous increase in the $V E G F$ mRNA and $V E G F$ protein of muscular fibers [6]. Myllyharju et al. explored $V E G F$ gene expression and observed that five training sessions managed to decrease response of the expression of Transforming Growth Factor Beta (TGF- $\beta$ ), FGF, and $V E G F$ to one acute training session [7]. VEGF expression depends on a wide range of factors, including hormones, growth factors, and oxygen density. When the oxygen is lacking, Hypoxia Inducible Factors $\left(\mathrm{HIF} \alpha_{1}\right.$ and $\left.\mathrm{HIF} \alpha_{2}\right)$ bind to the $V E G F$ - $a$ gene promoter and increase $V E G F$-a expression. In ischemic conditions, HIF-1a, in downstream, increases many molecules such as $V E G F$ and its receptor, which in turn upregulates $V E G F$ and increases its neurotrophic effect on endothelial cells and neurons following the hypoxic condition. While doing physical exercise, the acute and chronic effects of training on $V E G F$ have as a potent factor in angiogenesis. A body of research showed that endurance training helped increase the factors involved in angiogenesis in different organs. Training studies showed that increasing angiogenesis occurs at a $70 \%-80 \%$ threshold of maximum oxygen consumed $\left(\mathrm{VO}_{2 \mathrm{MAX}}\right)$ in skeletal muscle. However, a high load of endurance training at a threshold of $45 \%$ of $\mathrm{VO}_{2 \mathrm{MAX}}$ has no effect on angiogenesis in skeletal muscle [8]. Another angiogenesis index is the Fibroblast Growth Factor (FGF). It belongs to the family of growth factors and is involved in angiogenesis, treatment of injuries, and fetal development [9]. FGF-21 has been introduced as hepatokine/myokine/adipokine and is primarily expressed in the liver and muscles and plays a critical regulatory role in glucose and fat metabolism in humans and rodents [10]. FGF-21 stimulates glucose uptake in adipocytes by inducing GLUT-1 and inhibits glucagon secretion by pancreas alpha cells [11]. Moreover, increased FGF-21 turns the white adipose tissue to brown by increasing the protein level of Peroxisome Proliferator-Activated Coacti- vator 1 Alpha (PGC-1 $\alpha$ ) [12] and activating the AMPK/ SIRT1/PGC-1 $\alpha$ pathway, which indicates $F G F-21$ potential as a treatment of obesity [13]. Related studies showed that FGF-21 level increases after the training among overweight and obese patients [14]. However, Kruse et al. reported the ineffectiveness of endurance training in the circulation levels of $F G F-21$. Probably because the involved mechanisms are undetermined. In recent years, High-Intensity Interval Training (HIIT) has been known as an effective training intervention, which can benefit more than Medium-Intensity Interval Training (MIIT). As an instance, HIIT interventions have shown similar effects to Moderate-Intensity Continuous Training (MICT) on metabolic adaptations of the skeletal muscle, cardiovascular fitness, and body composition [15]. Moreover, HIIT causes a significantly higher increase than MIIT in the serum level of $F G F-21$. The existing body of research showed that $F G F$ 21 is increased in response to acute physical training. Yet, no change or reduction has been reported in this hormone in response to the training $[16,17]$.

Besides physical training, the existing research has shown that some herbs are effective in patients with cardiovascular diseases [18]. In Iranian traditional medicine, one effective herb for this purpose is fenugreek. Interestingly, this herb has a wide range of therapeutic effects, including the antiarthrosclerosis and anti-inflammatory effects, as well as the effects on controlling blood fat, lipid, blood pressure, and glyceride [19]. Fenugreek enjoys a hot and dry nature, and its leaves are effectively used to relieve cold coughs, splenomegaly, hepatitis, backache, and cold bladder. Besides, the herb seeds have topical laxatives, anti-inflammatory, and sore joint relieving effects. Its brewed drink mixed with honey has been recommended to treat shortness of breath and internal swelling. The seeds are especially beneficial. Several recent studies have proven the effectiveness of fenugreek seeds on reducing cholesterol [20]. Most therapeutic effects of fenugreek seeds observed in related studies point to the antioxidant, anti-inflammatory, and prebiotic effect of its active components. Research has also shown that this herb has an anti-inflammatory and anti-oxidant effect on animal models with infarction [21]. Despite the widespread use of fenugreek seeds in traditional medicine, no related research was found to explore the effect of this herb in combination with interval training on angiogenesis indices. Thus, because of the contradictory findings from different studies exploring different intensities of training and the effect of consuming herbal supplementary medicines, the present research aimed to explore the effect of interval training combined with the consumption of fenugreek seeds on the gene expression of $F G F-21$ and $V E G F$ in patients with coronary artery occlusion. 


\section{Materials and Methods}

The present quasi-experimental research had a pre-test, post-test design. The target population comprised all men with CAD aged between 55 and 65 years. They visited Rouhani and Shahid Beheshti hospitals in Babol City, Iran (2018-2019) and had no experience of regular physical activity and no previous consumption of fenugreek seeds (for at least the past six months). They were invited to participate in the research through a public announcement. Among all patients willing to participate in the research, 32 patients were selected. After being physically examined by a physician and signed an informed consent form, they entered the study. They were randomly divided into four groups: the control, the fenugreek consumption only, the training only, and the training + fenugreek consumption.

\section{The training protocol}

The training protocol involved 8 weeks of interval training in running, 3 sessions a week with an intensity of $55 \%-65 \%$ of the trainees' Heart Rate Reserve (HRR) and a gradual increase in intensity. The training protocol involved indoor running. Every session began with 10 minutes of general warm-up, including light stretching movements to dynamically involve all body limbs and the sessions ended with 10 minutes of cooling down. The main training aimed to reach the target intensity and was performed wearing a Polar sport watch to display the heart rate. The training protocol is presented in Table 1 [22].

\section{Fenugreek seed extract consumption protocol}

Fenugreek seeds were supplied from the countryside of Kermanshah City, Iran, and were then powdered. One thousand grams of the powder was inserted in a 2-L Erlenmeyer flask, and then $2 \mathrm{~L}$ of distilled water and ethanol (96\%) were added. The content was soaked for 48 hours and then was filtered through filter papers. Next, a rotavapor was used to extract the alcohol. The remaining content was concentrated and dried [23]. The subjects in the fenugreek only and training + fenugreek groups consumed $10 \mathrm{mg} / \mathrm{kg}$ of the fenugreek seed extract for 8 weeks (every day at 6:00 PM).

\section{Blood sampling and buffy coat preparation}

Blood samples (5 $\mathrm{mL}$ from the subjects' brachial vein) were taken 24 hours before the intervention and 48 hours after the last day of the intervention (training, fenugreek only, training + fenugreek), after 24-hour fasting in Pasteur Laboratory in Babol. To prepare the buffy coat, the blood was centrifuged at $3000 \mathrm{rpm}$ for $7 \mathrm{~min}$. The resultant white substance between the red globule layer in the bottom and plasma on the top was the buffy coat. To segregate the buffy coat, a 1000-sampler was used, and this step was done gradually. The aim was to have DNA extracted from the buffy coat equal to 5-10 times as much as the total blood's DNA.

To extract RNA, about $100 \mathrm{~mL}$ of the buffy coat was inserted in a micro-tube without any RNAase, and then $1 \mathrm{~mL}$ of TRIzol (that of the RNA extraction content by Sigma Corporation) was added. The micro-tube was centrifuged for 15 minutes at $2^{\circ} \mathrm{C}-8^{\circ} \mathrm{C}$ and a speed of $12000 \mathrm{rpm}$. Finally, the sediment was solved into Diethyl Pyrocarbonate (DEPC) treated water and stored at $-70^{\circ} \mathrm{C}$. Except for the first step, which was done under an ordinary hood due to the toxicity of TRIzol, all the other steps were conducted under a luminary hood. The extracted RNA was quantitatively measured via spectrophotometry and agarose gel electrophoresis. cDNA was made using a Fermentas kit (made in Germany). To develop the primers, all the existing limits were taken into account, and the Gen Runner (5.5.51) and Oligo 7.0 were used. After that, their specificity was checked in Basic Local Alignment Search Tool (BLAST) on the National Center for Biotechnology Information (NCBI) website. Table 2 presents the primers developed for this aim.

After a reverse transcription reaction to propagate the target segment and quantitative measurement of gene expressions, the real-time PCR was performed on the cDNA using SYBR Green dye. To determine the efficiency of primers, we used the LinRegPCR in which one group is set for the target samples with a pair of primers, and then for each group (each pair of primers), the efficiency was estimated. After examining all real-time PCRs, the resultant efficiencies were averaged to estimate the final efficiency. After the real-time PCR, the raw data were collected and analyzed.

\section{Data analysis procedure}

Descriptive statistics were used to analyze the data. Within-group and between-group changes were analyzed with pre-test, post-test design through 2-way repeated measures ANOVA and Tukey's test. The significance level for all cases was set at $\alpha \leq 0.05$. All statistical procedures were done using GraphPad prism 8 and Excel.

\section{Results}

Figure 1 shows the electrophorese of the extracted RNA on an agarose gel. As it can be observed, the presence of S28 and S18 RNA bands of ribosome show the healthy and ideal quality of the extracted RNA.

The results summarized in Table 3 indicate significant differences between the pre-test and post-test in terms of 
Table 1. Training protocol

\begin{tabular}{cccc}
\hline Week & The Intensity of Training (\%) & The Intensity of Rest (\%) & Total Training Time (min) \\
\hline 1 & 55 & 35 & 50 \\
\hline 2 & 55 & 35 & 50 \\
\hline 3 & 60 & 35 & 60 \\
\hline 4 & 60 & 40 & 60 \\
\hline 5 & 65 & 45 & 65 \\
\hline 6 & 65 & 45 & 65 \\
\hline 8 & 65 & 45 & 65 \\
\hline & 65 & 45 & Quarterly of \\
\hline
\end{tabular}

changes in the gene expression of VEGF and $F G F-21$ $(\mathrm{P}<0.0001)$. Within-group changes showed that the mean ratio of $F G F-21$ gene expression in the training-only group, fenugreek-only group, and the training + fenugreek group was significantly increased from the pre-test to the post-test as compared to the control group ( $\mathrm{P}<0.0001)$. Tukey's test results showed a statistically significant increase in the mean expression of $F G F-21$ in the training only, fenugreek only, and training + fenugreek groups compared to the control group $(\mathrm{P}<0.0001)$. The training + fenugreek group showed a higher statistically significant increase than the training only and the fenugreek only groups $(\mathrm{P}<0.0001)$. However, the training-only group showed no statistically significant difference with the fenugreek-only group $(\mathrm{P}=0.4987$ ) (Figure 2 ).

Moreover, within-group comparison results showed that the mean coefficient of variation of the $V E G F$ gene expression was significantly increased more than in training-only group $(\mathrm{P}<0.0001)$, fenugreek-only group $(\mathrm{P}=0.0004)$, and fenugreek + training group $(\mathrm{P}<0.0001)$ compared to the control group. The fenugreek + training group showed a statistically significant increase compared to the trainingonly group $(\mathrm{P}=0.0181)$ and the fenugreek-only group $(\mathrm{P}<0.0495)$. However, the training-only group showed no statistically significant difference with the fenugreek-only group $(\mathrm{P}=0.9999)$ (Figure 3).

\section{Discussion}

The present research explored the effect of interval training and consumption of fenugreek seeds on $V E G F$ and $F G F-21$ gene expressions in patients with coronary artery diseases. The results revealed that the ratio of $V E G F$ and FGF-21 gene expression was increased in patients with CAD after an interval training combined with the consumption of fenugreek seeds. No statistically significant difference was observed between the effect of the interval training and the consumption of the fenugreek seeds. Yet, the combined group (training + fenugreek) showed a significantly increased effect. FGF family members possess an intracellular activity, paracrine, and endocrine with different effects on metabolism and the potential activities of the cardiovascular system. There is evidence that the endogenous gland family members are correlated with metabolic markers and prognosis of CAD. FGF-21 is a new member of the FGF family and plays a potentially crucial role in cardiovascular diseases and especially atherosclerosis. It has been shown that $F G F-21$ level is strongly correlated with cardiovascular risk and conditions such as blood cholesterol,

Table 2. Primers used in gene identification

\begin{tabular}{cccc}
\hline Gene & Forward Primer 3'-5' & Reverse Primer 3'-5' & Annealing Temperature \\
\hline FGF21 & TGAGGATCCAGCCGAAAGAG & CAGCACAGAAACCCACAGTC & $60^{\circ} \mathrm{C}$ \\
VEGF & GGCCAGCACATAGGAGAGAT & TTTAACTCAAGCTGCCTCGC & $60^{\circ} \mathrm{C}$ \\
\hline & & $\begin{array}{l}\text { Quarterly of } \\
\text { The Horizon of Medical Sciences }\end{array}$
\end{tabular}


Table 3. ANOVA results of the coefficient of variance for $V E G F$ and FGF21 gene expression

\begin{tabular}{|c|c|c|c|}
\hline & & $\mathbf{F}$ & $\mathbf{P}$ \\
\hline \multirow{3}{*}{ FGF-21 } & Group $\times$ time & 38.77 & $<0.0001$ \\
\hline & Time & 1.043 & $<0.0001$ \\
\hline & Group & 41.1478 & $<0.0001$ \\
\hline \multirow{3}{*}{ VEGF } & Group $\times$ time & 33.90 & $<0.0001$ \\
\hline & Time & 8.896 & $<0.0001$ \\
\hline & Group & 36.57 & $<0.0001$ \\
\hline
\end{tabular}

hypertension, diabetes, and obesity. Yet, different metabolic effects of $F G F-21$ have already been shown in experimental animal models. These effects show that $F G F-21$ may have a protective effect on the cardiovascular system and lower the risk factors. There is evidence for the protective effect of $F G F-21$ on endothelial damage and atherosclerosis through plaque formation and the ischemic damage of cardiac myocytes associated with oxidative stress [9].

Moreover, in today's world characterized by the evergrowing use of technology and mechanical life, there is less physical activity. The diseases induced by low physical activity are on the rise, and the most prevalent ones are cardiovascular diseases [24]. FGF-21 level is increased in physical training [15]. Much research revealed that the gene expression of $F G F-21$ increases after physical training, primarily induced by this hormone's production in hepatocytes. This production is upregulated due to the increased ratio of glucagon to insulin (an increase in glucagon and a decrease in insulin) [16]. High-Intensity Interval Training (HIIT) can significantly increase the serum $F G F-21$, while MediumIntensity Interval Training (MIIT) has no significant effect on this hormone $[11,15] . F G F-21$ expression and secretion are upregulated by an over-expression of Akt1. Regarding the activation of Akt1 after physical exercises, Chavanelle et al. showed recently that HIIT leads to higher activation of Aktl than the MIIT. Thus, an increase in the expression of FGF2 1 as a result of interval training is due to the activation of Akt1 [25]. The present findings are consistent with a body of research $[13,18,25]$ and inconsistent with some others [26]. The inconsistency of findings is due to the genetic measurement of factors such as $F G F-21$ and VEGF and the measured tissue. Lloyd et al. investigated the angiogenesis of skeletal muscles in response to physical training to explore the angiogenesis process. The results revealed that in the training group, VEGF increased 3-6 times within 12 days; yet, no change was observed in the control group [27]. There is evidence that in ischemic and hypoxic condi-

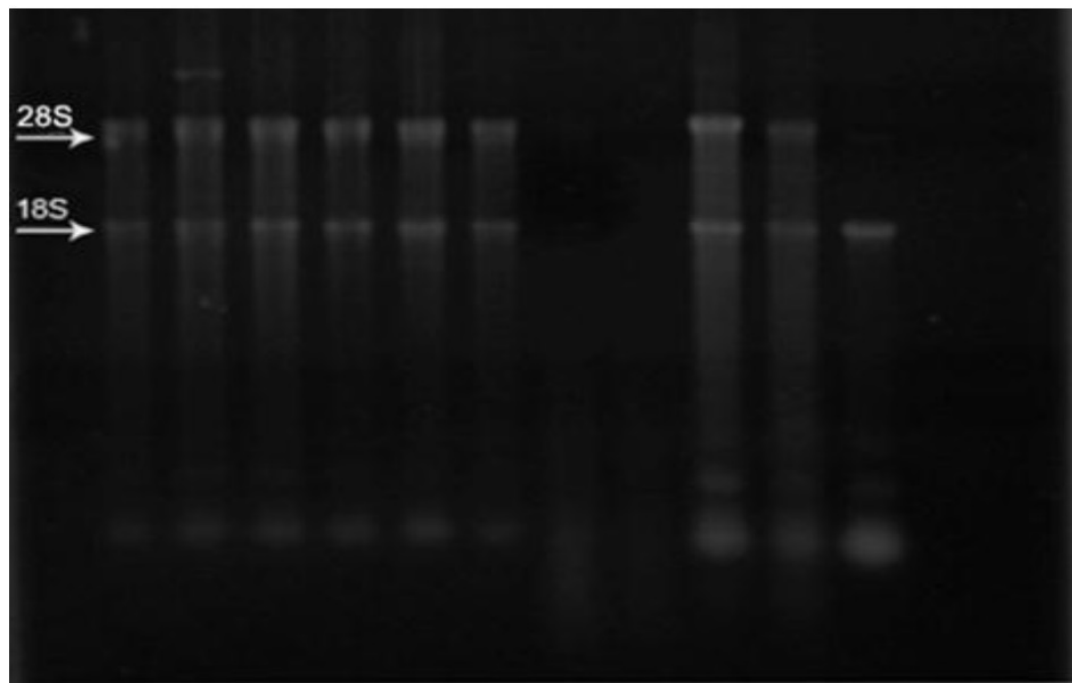

Figure 1. The electrophorese of the RNAs extracted on agarose gel

Quarterly o

The Horizon of Medical Sciences 


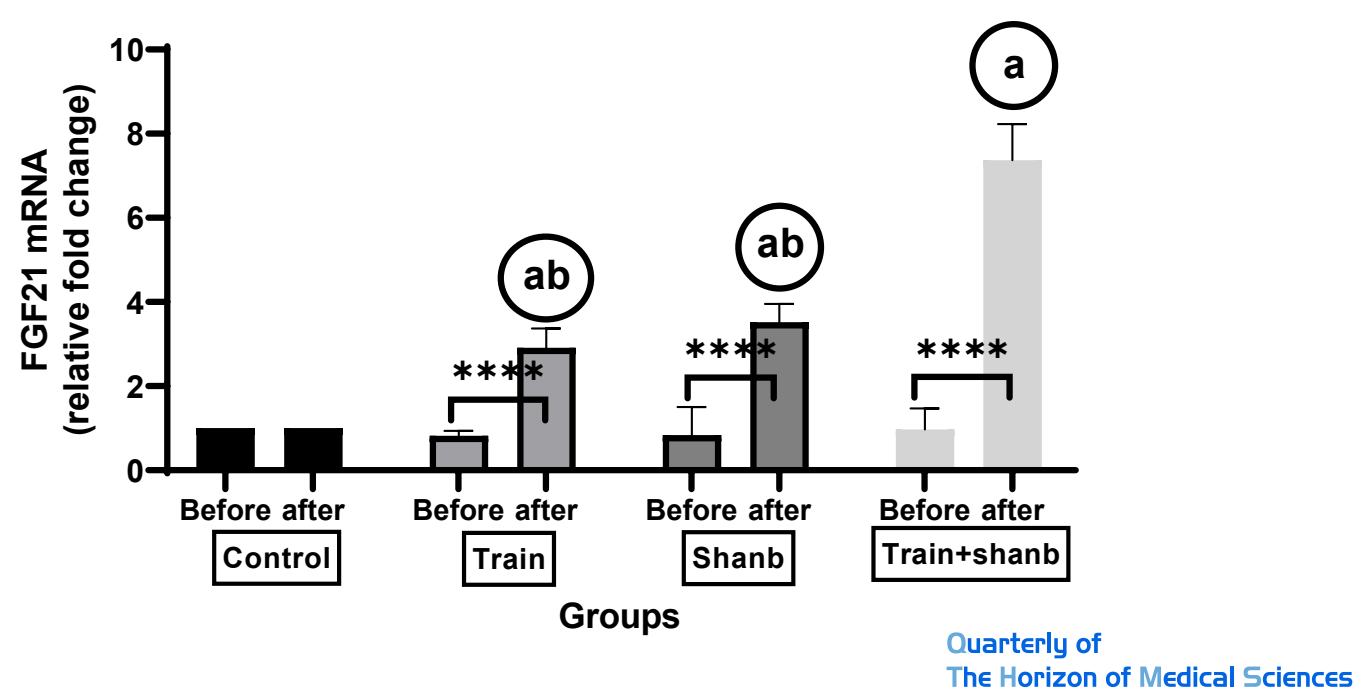

Figure 2. Comparative results of $F G F-21$ gene expression in different research groups from the pre-test to post-test

Before: 24 hours before the interventions; After: 48 hours after the last day of the intervention; Control: Control group; Train: training group; Shanb: fenugreek; Train-Shanb: training + fenugreek; ${ }^{\mathrm{a}}$ significant compared to the control group $(\mathrm{P}<0.0001)$; ${ }^{\mathrm{b}}$ significant compared to the fenugreek + training group $(\mathrm{P}<0.0001) ; * * * * \mathrm{P}<0.0001$.

tions, the Hypoxic Induction Factor (HIF1) was increased. HIF-1 activation initiates functional adaptations (e.g. the gene expression of $V E G F$ ), which can reduce the adverse effects of exposure to hypoxia. After secretion, HIF-1 can detect Hypoxic Reactive Elements (HRE) located on the target genes in the nucleus. The reaction HIF-1 and HRE initiates the transcription of the target genes (those related to $V E G F)$ [28].
Overall, the hypoxia occurring as a result of the interval training activates pro-angiogenesis pathways. As a result of adaptation to training, the upregulation of $V E G F$ and FGF21 happen as strong angiogenesis stimulants. A body of research has shown that in cardiac patients, aerobics has been more effective than other exercises on endothelial functioning. This training managed to increase the vasodilation induced by the bloodstream by $1 \%-5 \%$ [29]. It has been shown that interval training increases shear stress due

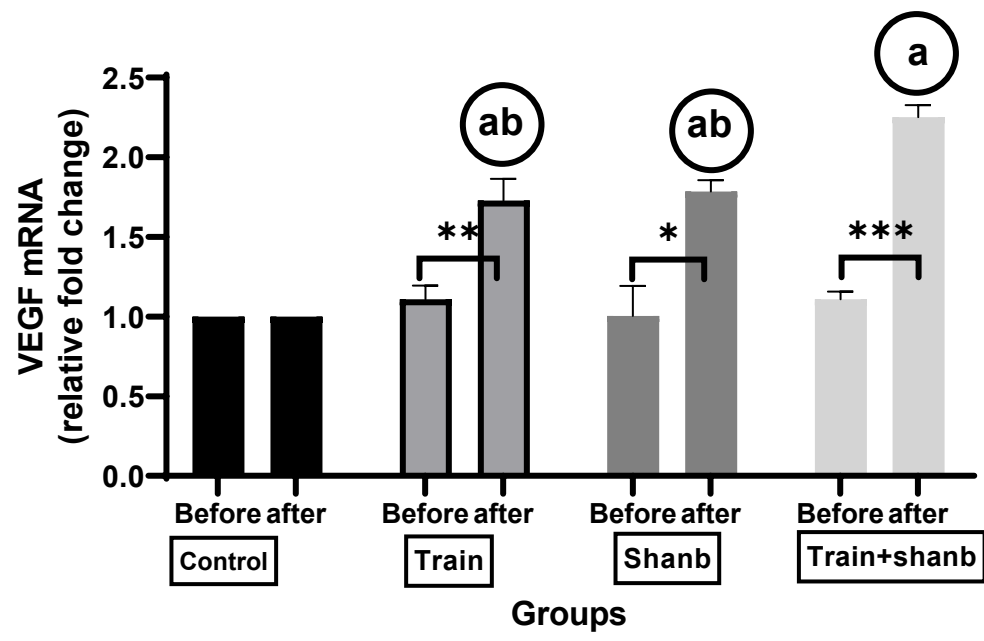

Quarterly of

The Horizon of Medical Sciences

Figure 3. Comparative results of $V E G F$ gene expression in different research groups from the pre-test to post-test

Before: 24 hours before the interventions; After: 48 hours after the last day of the intervention; Control: Control group; Train: training group; Shanb: fenugreek; Train-Shanb: training + fenugreek; ${ }^{a}$ significant compared to the control group $(\mathrm{P}<0.05)$; ${ }^{\mathrm{b}}$ significant compared to the fenugreek + training group $(\mathrm{P}<0.05) ; * * * * \mathrm{P}=0.0001 ; * * 0.0001<\mathrm{P}<0.05 ; * \mathrm{P}<0.05$. 
to topical intermittent recurrences [30]. Moreover, according to recent investigations, fenugreek is known for its antiatherosclerosis, anti-inflammatory, and antioxidant effects [31]. Research findings showed that consuming fenugreek seeds besides swimming exercises had a strong therapeutic effect on reducing cholesterol and artery occlusion besides improving diabetes parameters [2]. It has also been found that obese people with high lipid tissue need to have a wider vascular bed to allow blood circulation. Thus, this adaptation to training and fenugreek consumption can, in the long run, improve atherosclerosis. Yet, further in-depth research is needed on this issue.

Although there is no direct investigation of the effect of fenugreek on angiogenesis, it has been shown that some of its ingredients, including a group of phenols with low molecular weight, have a particular effect on the treatment of cardiac diseases. Moreover, a body of research has attested to the anti-oxidant effect of fenugreek due to the capability of flavonoids in inhibiting lipid peroxidation and protection against anti-oxidative stress. Flavonoids can regulate some phases of angiogenesis, such as cell migration and microcapillary tube formation [32]. Fenugreek improves the maximal and sub-maximal aerobic function [33]. Besides, the above-mentioned studies showed that fenugreek extract significantly reduces the atherogenic index. Fenugreek possesses bitter saponins such as protodioscin. A body of research has proven the effectiveness of diosgenin (a form of protodioscin and dioscin) in lipid and glucose metabolism. Diosgenin increases the Peroxisome Proliferator-Activated Receptor Y (PPARY) level in the white tissue and induces cell differentiation, and reduces the size of fat cells. These events would increase adiponectin secretion, which inhibits inflammation in fat cells. Moreover, diosgenin reduces the triglyceride level and mRNA expression in lipogenetic genes [20].

\section{Conclusion}

An increase in the CV of $V E G F$ and $F G F-21$ gene expression in the research groups probably lead to the preangiogenetic functioning of endothelial cells. HIIT might cause a faster adaptation to aerobic interval training in the body. The results revealed that a combination of the interval training and consumption of fenugreek seeds managed to increase the coefficient of variation of the $F G F-21$ and $V E G F$ gene expression and can probably positively affect the pro-angiogenesis pathway in patients with coronary artery occlusion.

One limitation of the present research was the small sample size and the measurement of few angiogenetic indices. Further research is required to know the potential mecha- nisms involved in the effect of the training and consumption of fenugreek seeds on larger samples using a wider range of indices.

\section{Ethical Considerations}

\section{Compliance with ethical guidelines}

This research project was approved by the Ethics Committee of Islamic Azad University of Babol (Code: \#IR. IAU.BABOL.REC.1398.091).

\section{Funding}

This research did not receive any grant from funding agencies in the public, commercial, or non-profit sectors.

\section{Authors' contributions}

All authors equally contributed to preparing this article.

\section{Conflicts of interest}

The authors declared no conflict of interest. 
تأثير تمرين دورهاى و مصرف عصاره دانه شنبليله بر بيان ثن FEF-21 و VEGF دو بيماران مبثلا به بيمارى عروق كرونر تمرئ

\author{
عباد روحبخش' (1)، "عليرضا برارى' [ـ، هاجر عباسزاده' \\ ا. كروه فيزيولوزى ورزشى، واحد آيثالثه آملى، داتشعاه آزاد اسلامى، آمل، ايران.

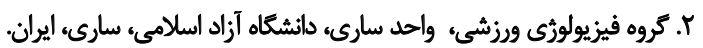

\begin{abstract}
حكبن

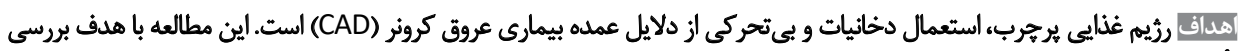

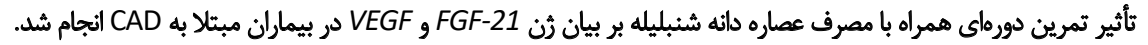

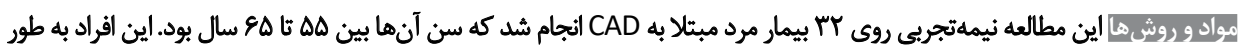

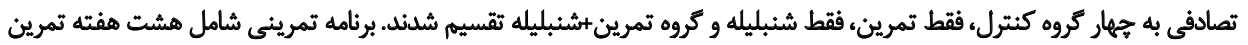

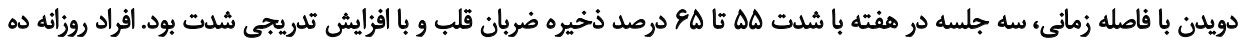

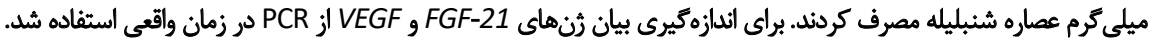

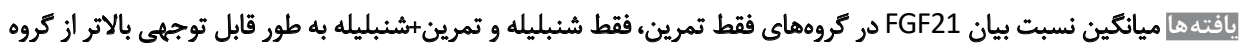

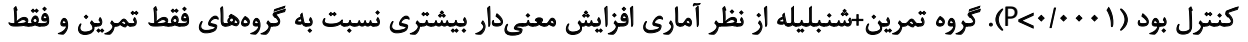

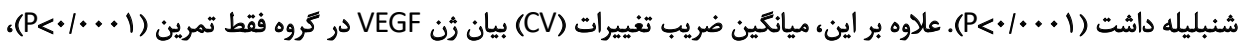

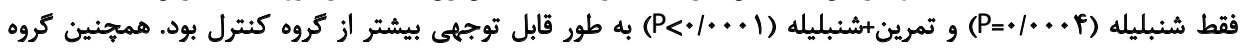

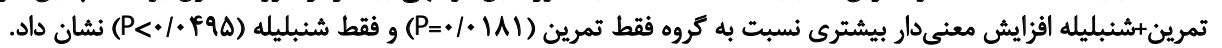

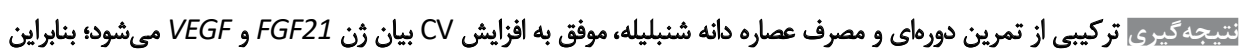

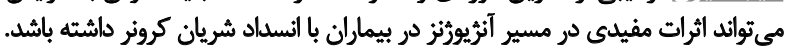

تاريخ دريافت: و شهريور

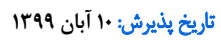

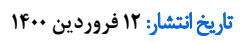

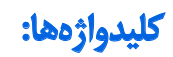

تمرين دورهاي؛ شنبليله؛

فاكتور رشد فيبروبلاست دورئيل

(FGF-21)؛

رشد اندوثليال عروقى فاكتي

كرونر (VEGF)

كرونر

تمرين بدنى، بدن را بسيار سازكار مي كند و مى تواند ميزان

مقدمه

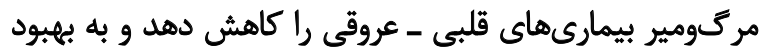

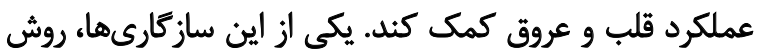

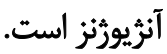

فاكتورهاى مختلف رشد در اين روش نقش دارند كه مهمترين

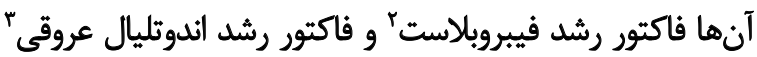

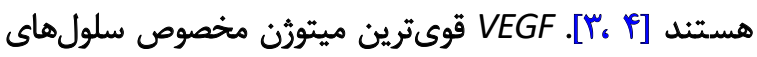
أندوتليال است [ه] كه به عنوان تنظيمكنينده اصلى آنزيوزثنز

شناخته مي شود [i[].

اين فاكتورهاى رشد اندوثليال عروقى، عملكرد بيولوزيكى خود

2. Fibroblast Growth Factor (FGF)

3. Vascular Endothelial Growth Factor (VEGF)

بيمارى عروق كرونر' بيش از ساير بيمارىها بر جهان غرونان غلبه

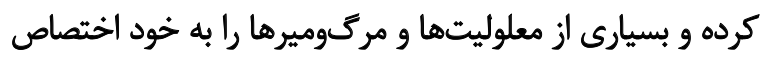

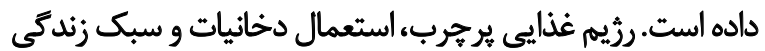

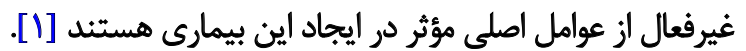

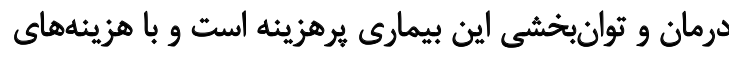

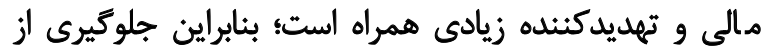

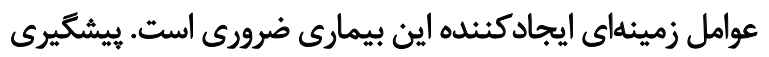

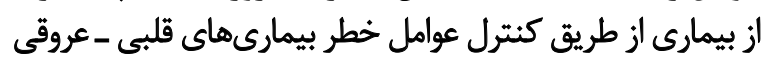

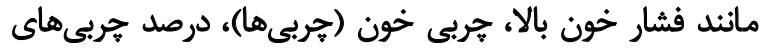

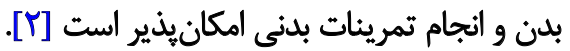

\title{
-
}

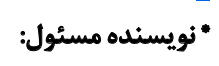

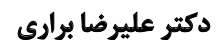

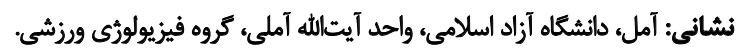

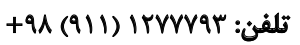

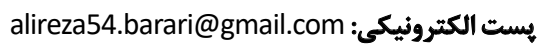


هياتوكين / ميوكين / آدييوكين معرفى شده و در كبد و عضلات بيان

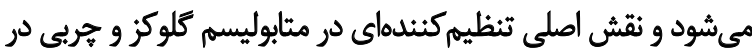
انسان و جوندكان دارد [ • [1]].

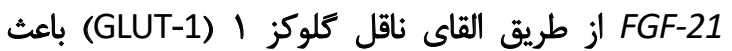

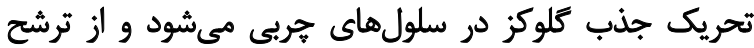

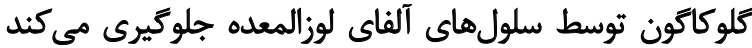

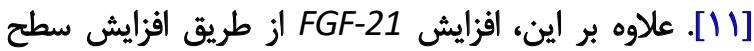

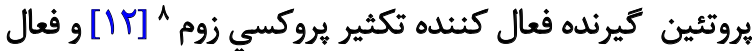

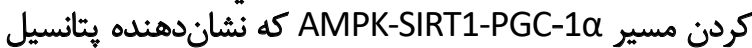

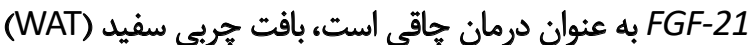

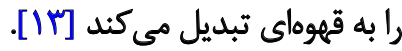
مطالعات مرتبط نشان دادند سطح FGF-21 بِ إز از تمرين در

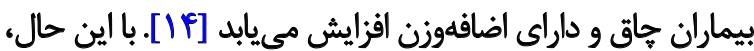

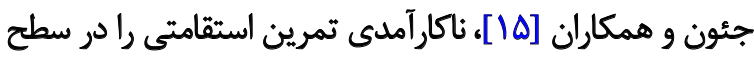

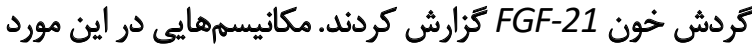

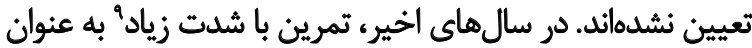

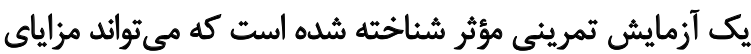

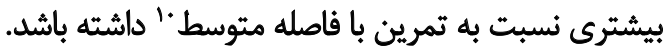

به عنوان مثال، آزمايشات HIIT اثرات مشابه تمرينات تداومى با شدت متوسط (MICT) را در سازكارى متابوليكى عضله اسكلتى، تئي،

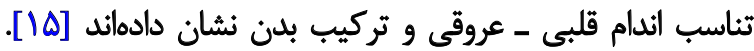

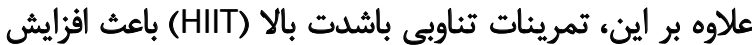

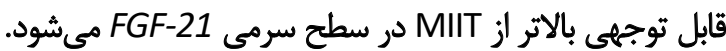

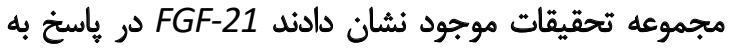

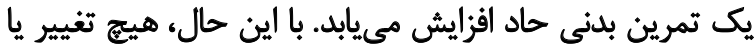

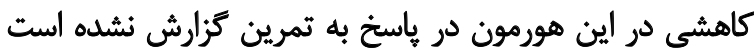
برخ [19، IV]

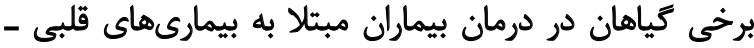

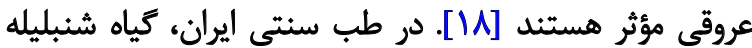

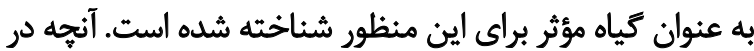

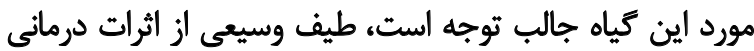

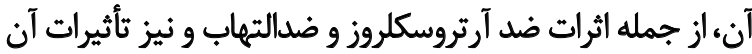

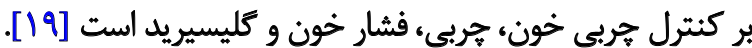

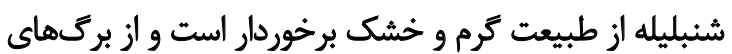

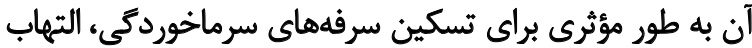

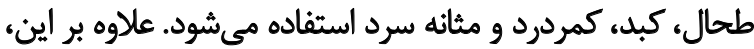

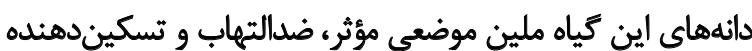

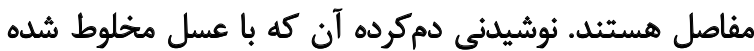

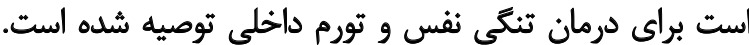

\section{PGC-1 $\alpha$}

9. High-Intensity Interval Training (HIIT)

10. Medium-Intensity Interval Training (MIIT)
را از طريق تأثير بر گيرندهاى تيروزين kinesis" در غشاى

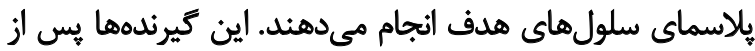

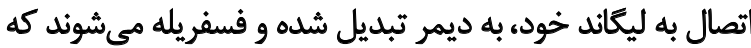

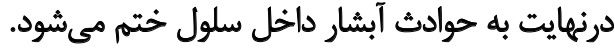

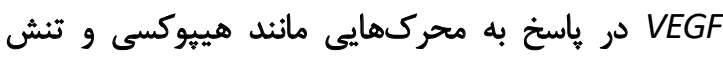

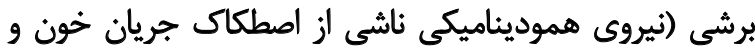

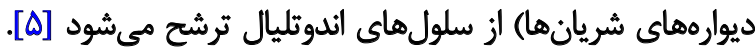

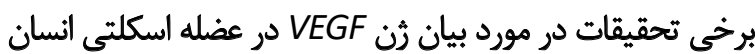

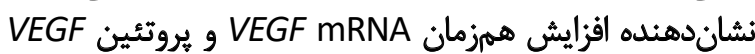

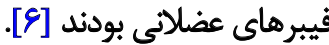

ميلىهارجوه و همكاران، بيان رن يعنى فاكتور رشد آندوثليال

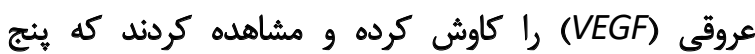
جلسه آزمايش موفق به كاهش بإسخ افزايش بيان فاكتون

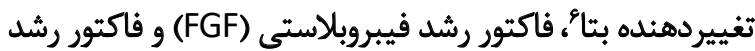

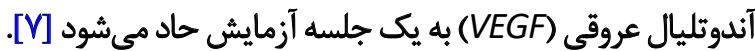

بيان VEGF به طيف تستردهاى از عوامل، از جمله هورمونها،

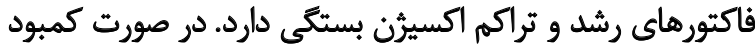

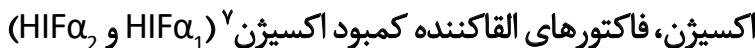

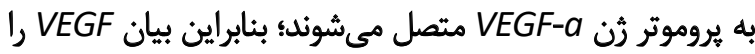

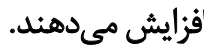

در شرايط ايسكميك، HIF-1a، در ثاييندست، بسيارى از

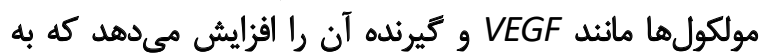

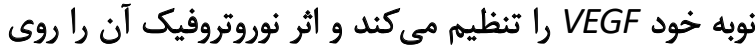

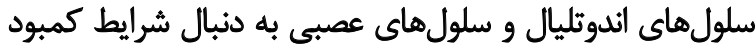

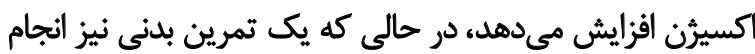

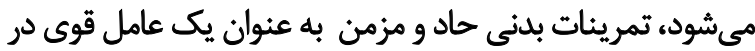

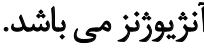

مجموعهاى از تحقيقات نشان دادند تمرين استقامتى به

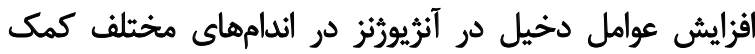

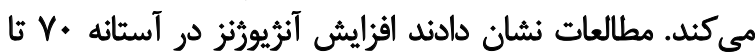

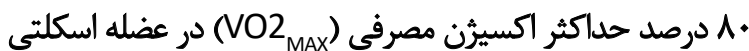

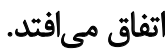
با اين حال، يكبار تمرين استقامتى زياد در آستانه هاf درصد

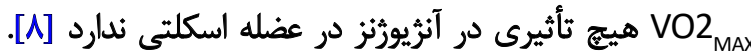

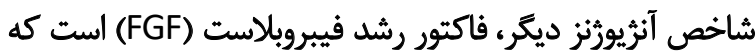

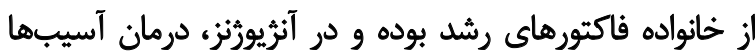

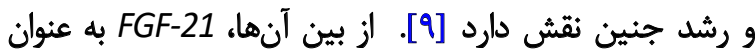

\footnotetext{
4. Receptor tyrosine kinases

5. Myllyharju

6. Transforming Growth Factor Beta (TGF- $\beta$ )

7. Hypoxia-Inducible Factors (HIFs)
} 


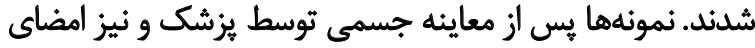

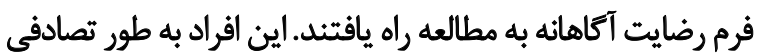

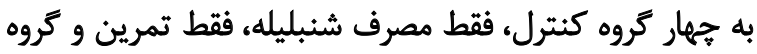
تمرين+مصرف شنبليله تقسيم شديند.

\section{يروتكل تمرين}

بروتكل تمرين شامل هشت هفته تمرين متناوب به صورت

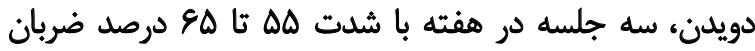

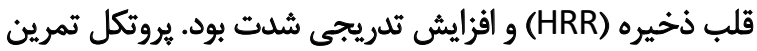

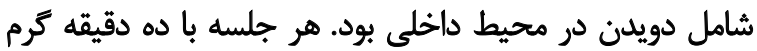

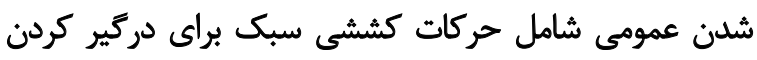

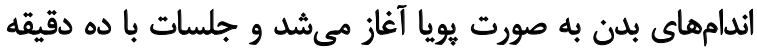
خنك شدن به بايان مىرسيد.

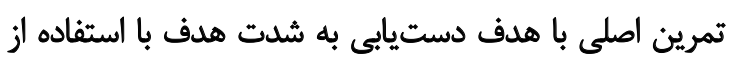

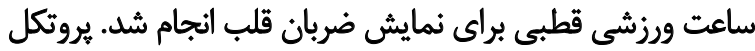
تمرين در جدول شماره ا [بr نشائ نشان داده شده است

\section{يووتكل مصرف عصاره داثه شنيليله}

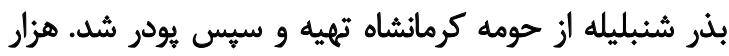

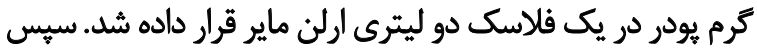

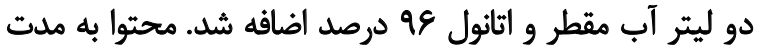

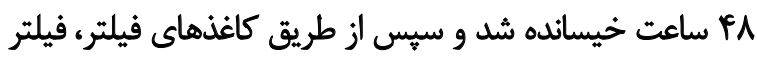

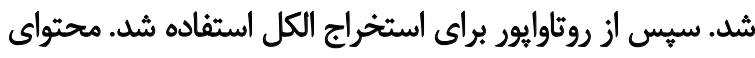

باقىمانده غليظ و خشك شد آنسائ.

افراد فقط در كروه شنبليله و گروههاي تمرين+شنبليله ده

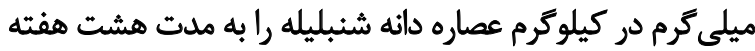

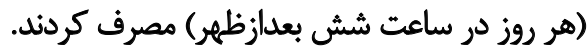

بذرها، مخصوصاً مفيد هستند. جندين مطالعه اخير تأثير دانه

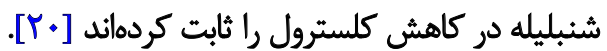
بيشتر اثرات درمانى دانه شنبليله كه در مطالعات مرتبط بـاني

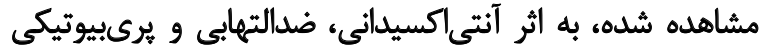

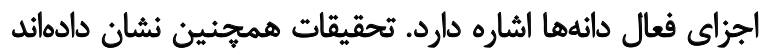

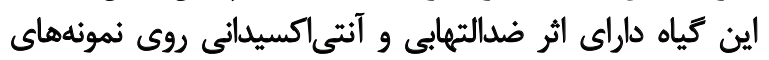

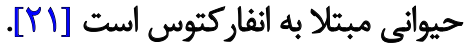

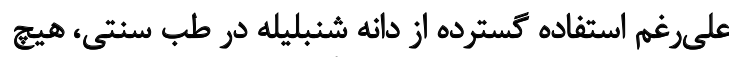

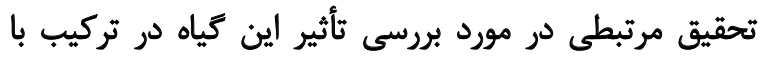

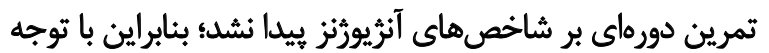

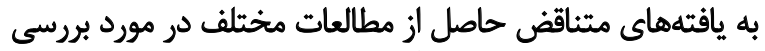

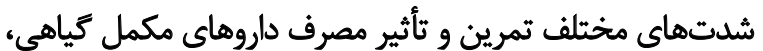

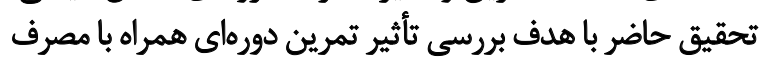

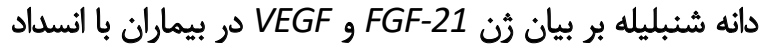

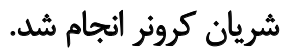

\section{مواد و روشها}

تحقيق حاضر از نوع نيمهتجربى با طرح قبل و بعد از آزمون

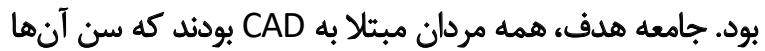

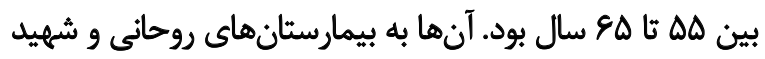

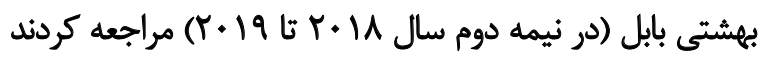

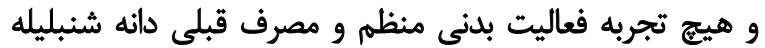
(حداقل در شش ماه كذشته) را نداشتند.

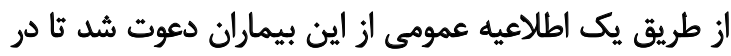

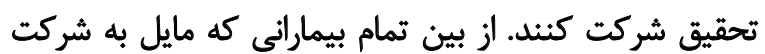

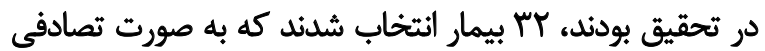

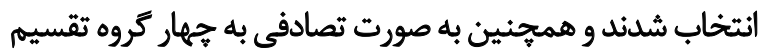

جدول ا. يروتكل تمرين بدنى مورد استفاده در بيروهش

\begin{tabular}{|c|c|c|c|}
\hline كل زمان تمرين (دقيقه) & شدت استراحت (درصد) & شدت تمرين (درصد) & هفته \\
\hline Q. & ra & $\Delta \Delta$ & 1 \\
\hline$\Delta$. & TA & $\Delta \Delta$ & $r$ \\
\hline 8. & ro & g. & $r$ \\
\hline 8. & f. & s. & $f$ \\
\hline 80 & fo & $9 \Delta$ & $\Delta$ \\
\hline $8 \Delta$ & PQ & $\varepsilon_{\Delta}$ & 8 \\
\hline 80 & $P \Delta$ & $\varphi_{\Delta}$ & $\gamma$ \\
\hline$v_{0}$ & $P \Delta$ & QD & $\wedge$ \\
\hline
\end{tabular}

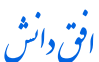


جدول ז. آغازكرهاي مورد استفاده در شناسايي ثن

\begin{tabular}{|c|c|c|c|}
\hline دماى أنيلينى & آغازيّر معكوس 'ب-'ه & آغازئر جلو "r-'ه & نे \\
\hline •عدرجه سانتى كراد & CAGCACAGAAACCCACAGTC & TGAGGATCCAGCCGAAAGAG & FGF-21 \\
\hline .ع درجه سانتي كراد & TTTAACTCAAGCTGCCTCGC & GGCCAGCACATAGGAGAGAT & VEGF \\
\hline
\end{tabular}

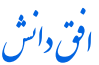

تر زير يك هود معمولى انجام شد، تمام مراحل ديكر

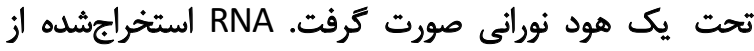

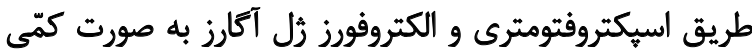

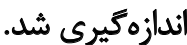

CDN A

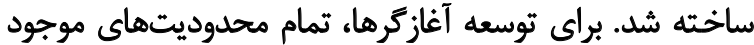

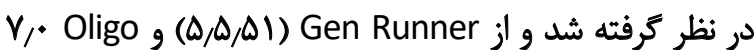

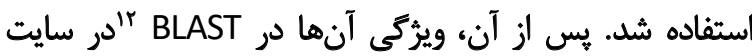

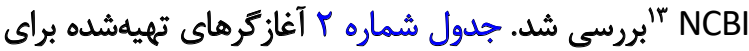

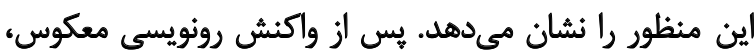

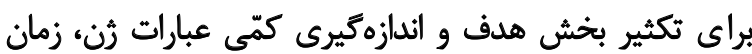

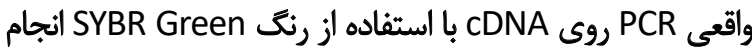

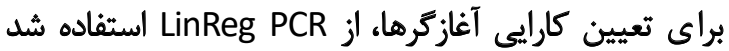

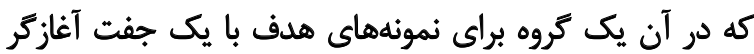

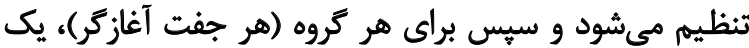

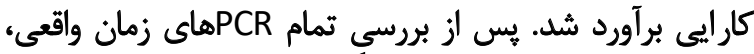

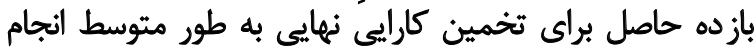

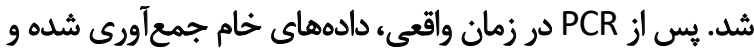

12. Basic Local Alignment Search TooL

13. National Center for Biotechnology Information

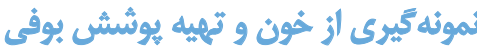

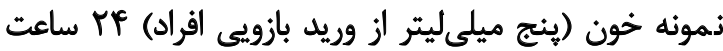

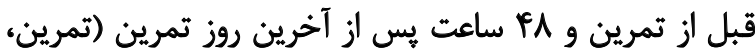

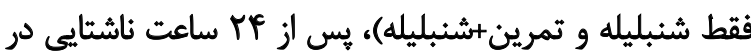
آزمايشكاه ياستور در بابل كرفته شد.

براى تهيه يوشش بوفى، خون با سرعت سه هزار دور در دقيقه

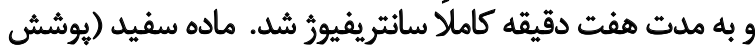

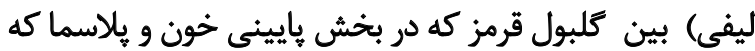

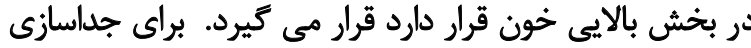

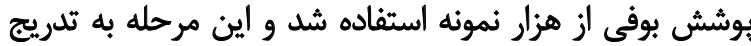

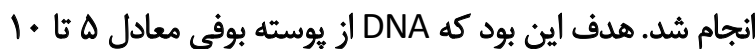

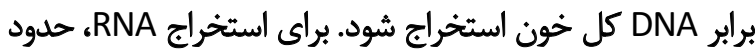

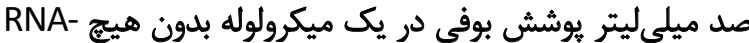

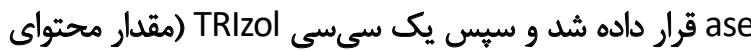

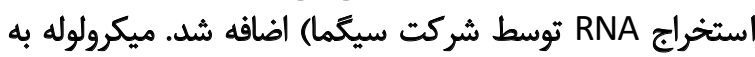

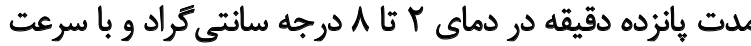

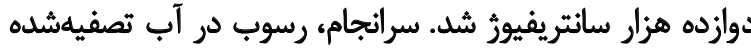

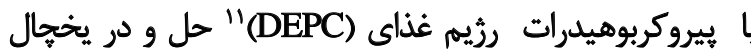

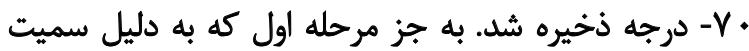

11. Diethyl pyrocarbonate

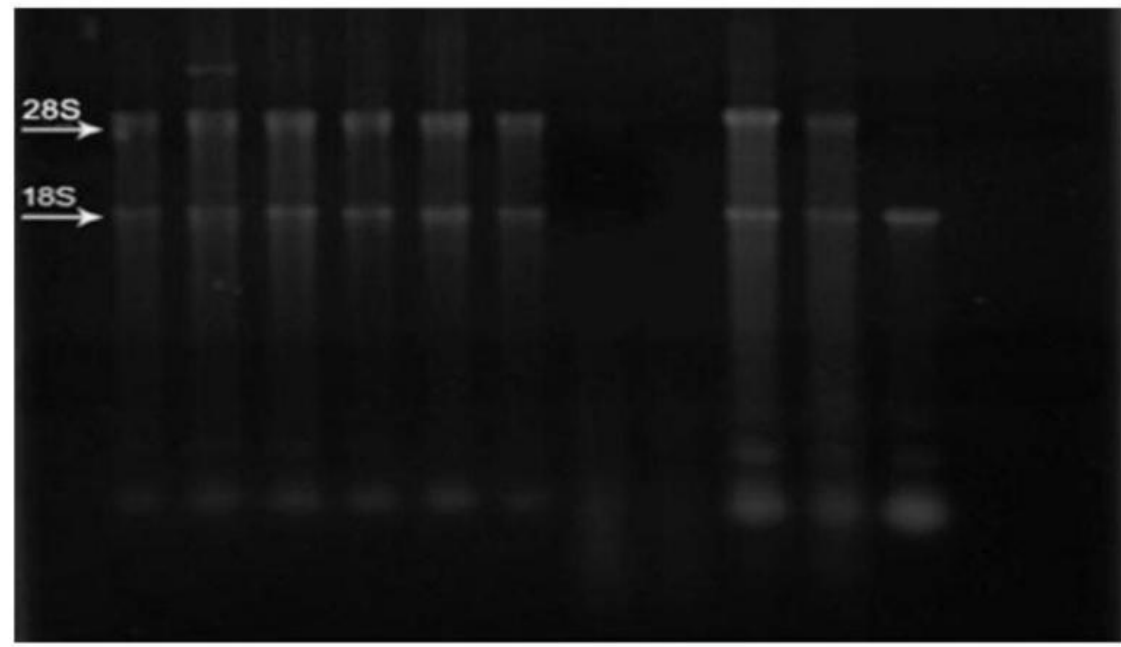


جدول r. ضرايب واريائس بيان رن FEFF و FGF (نتايج آزمون ANOVA)

\begin{tabular}{|c|c|c|c|}
\hline $\mathbf{P}$ & $\mathbf{F}$ & & \\
\hline.$/ . .1$ & rNW & كروه × زمان & \multirow{3}{*}{ FGF21 } \\
\hline$. / \cdots+1$ & $V / r r$ & زمان & \\
\hline $.1 \% \cdot 1$ & $P I / V A$ & كروه & \\
\hline $1 / . .1$ & $\pi / 9$. & كروه زمان & \multirow{3}{*}{ VEGF } \\
\hline.$/ . .1$ & NAQ & زمان & \\
\hline.$|\cdots|$ & $r g / \Delta V$ & كروه & \\
\hline
\end{tabular}

استخراجشده را نشان مى دهد.

تجزيه و تحليل شدند.

نتايج خلاصهشده در جدول شماره ب از نظر تغييرات بيان

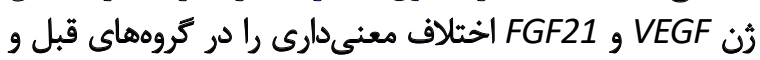

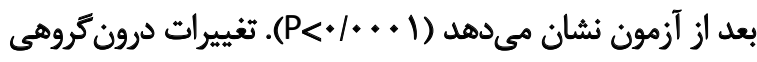

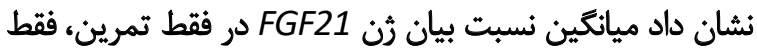

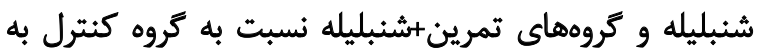

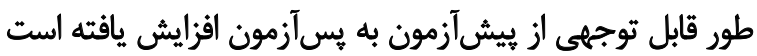
. $(P<1 \cdot \cdots 1)$

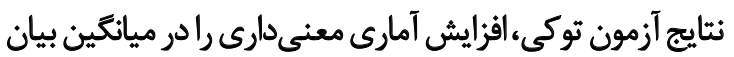

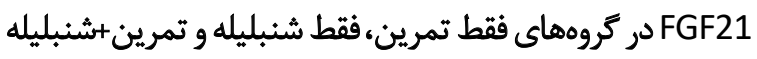

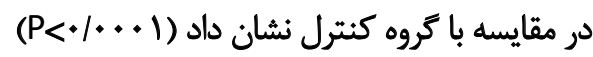

براى تجزيه و تحليل دادهها آزار توصيفى استفاده شد. تغييرات

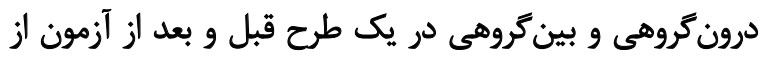

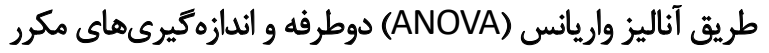

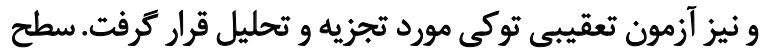

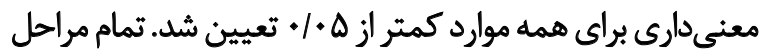

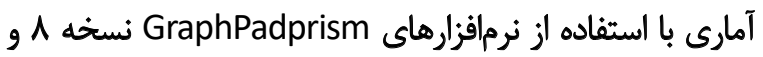

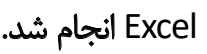

ياقتهها

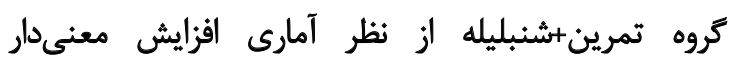

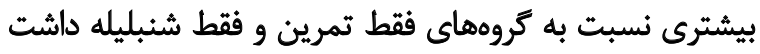

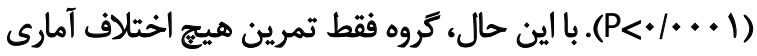

تصوير شماره ا الكتروفوز RNA استخراجشده روى خل

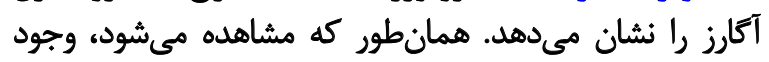

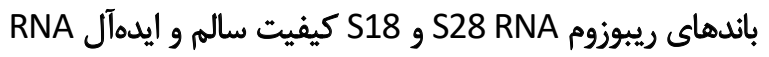

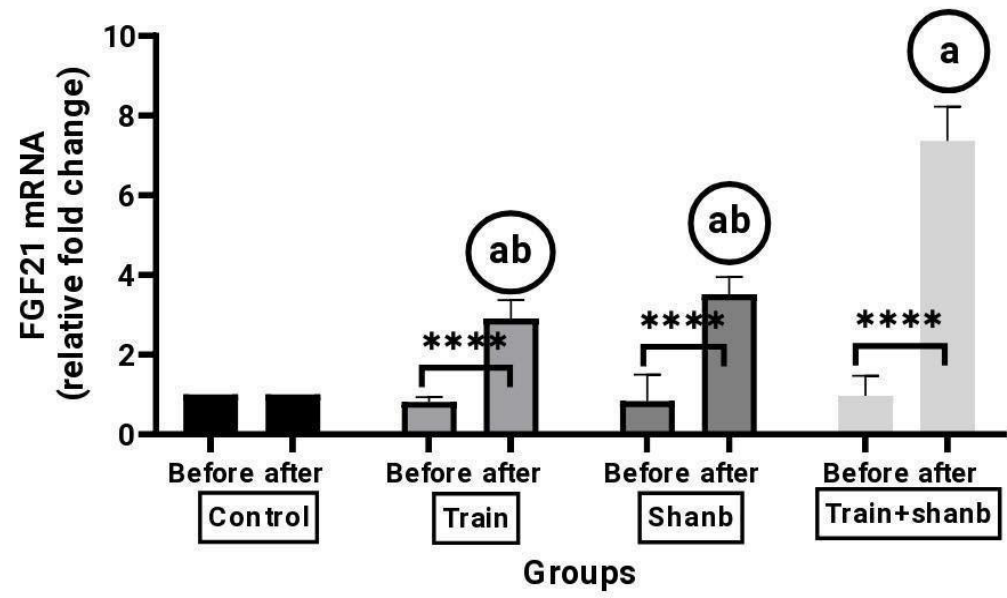

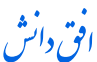
تصوير Y. نتايج مقايسه بيان رن FGF21 در كروهماى مختلف تحقيقاتى از بيشآزمون تا يسآزمون

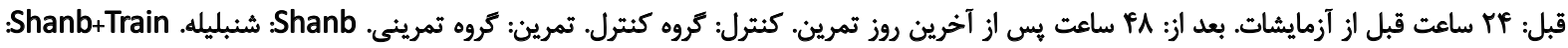

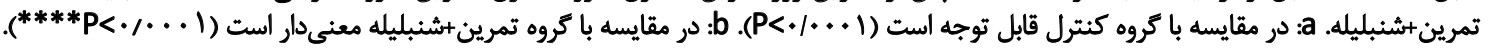




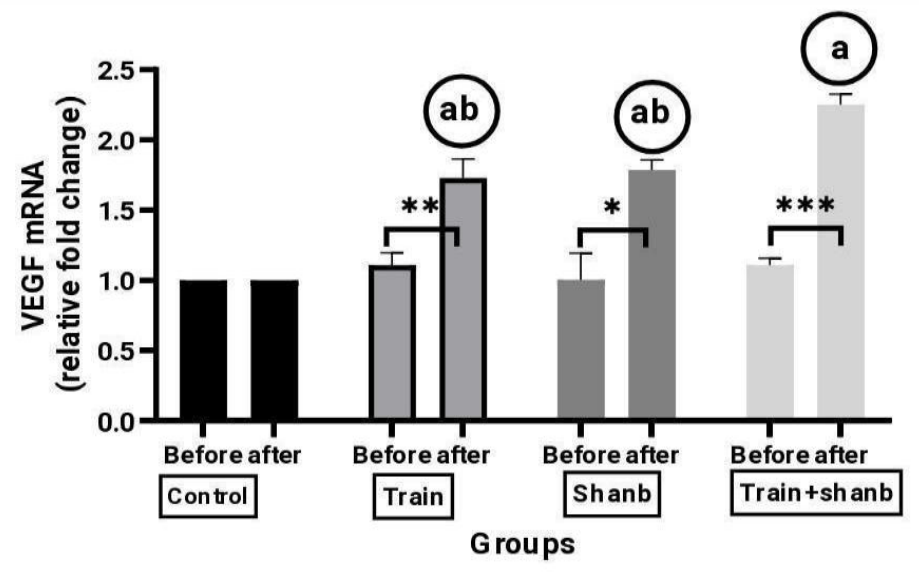

انوّنَ تصوير لا. نتايج مقايسه بيان ذن VEGF در كروهماى مختلف تحقيقاتى از بيشآزمون تا بسآزمون

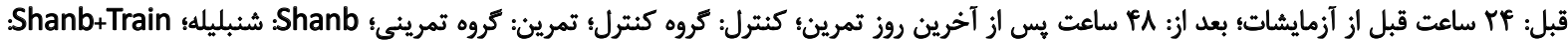

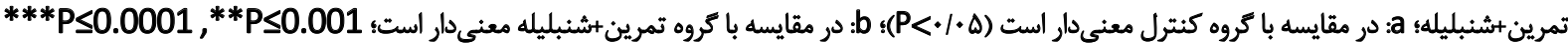

*P $\leq 0.05$

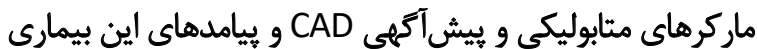

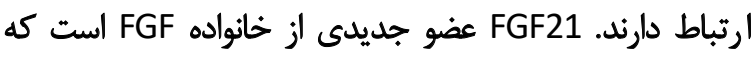

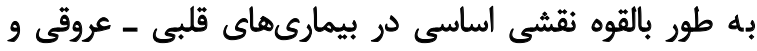
بهخصوص تصلب شرايين دارد. سطح FGF21 به شدت با خطر قلبى - عروقى و شرايطى

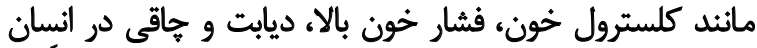

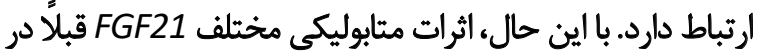

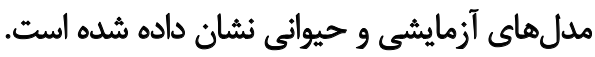
اينها نشان ميدهند كه FGF21 ممكن است اثر محافظتى

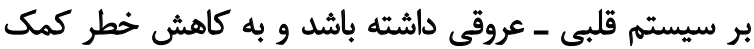

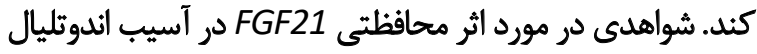

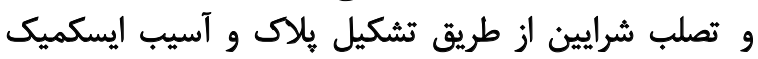
ميوسيتهاى قلبى مرتبط با استرس اكسيداتيو وجود دارد [9].

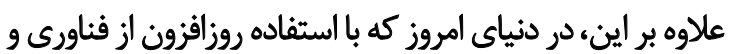

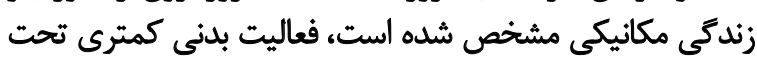

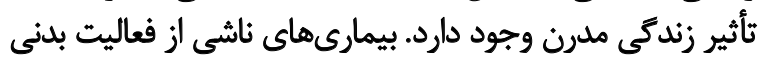

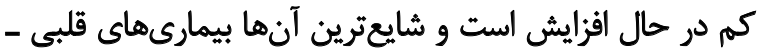

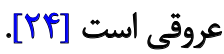

سطح FGF21 در تمرين بدنى افزرايش مي سيابد [1ه]. مجموعهايى

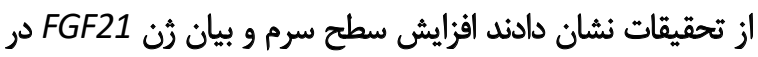

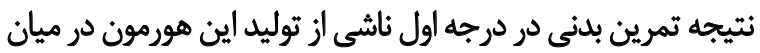

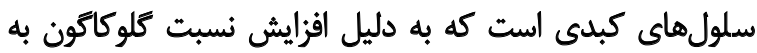

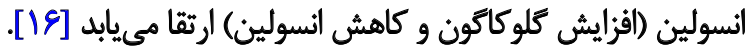
تمرين با شدت زياد (HIIT) مى تواند به طور قابل توجهي

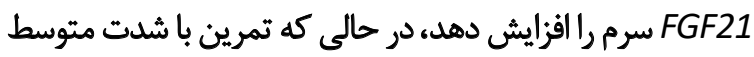

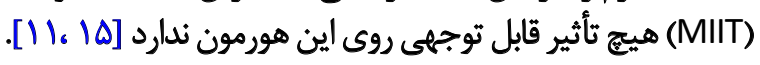

معنى دارى را با كروه فقط شنبليله نشان نداد (P=./F9AV)

$$
\text { (تصوير شماره Y) (ب) }
$$

علاوه بر اين، نتايج مقايسه درون تروهى نشان داد ميانكَين

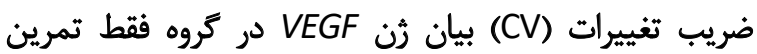
(P=) و

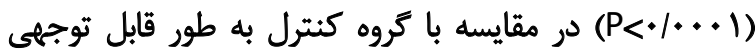

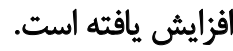

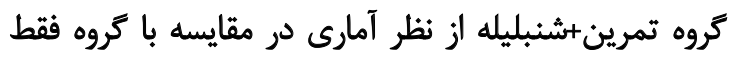

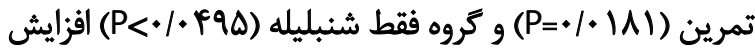

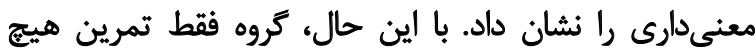

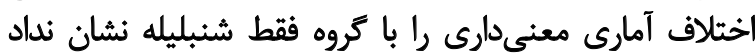

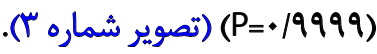

\section{بحث}

تحقيق حاضر به بررسى تأثير تمرين دورهاى و مصرف دانه

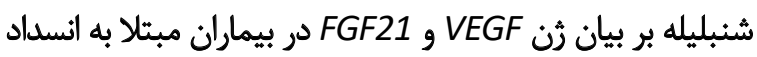

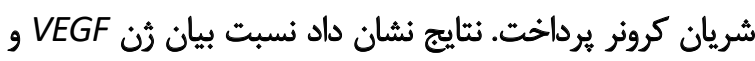

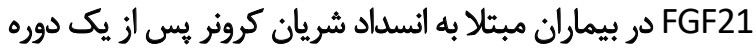

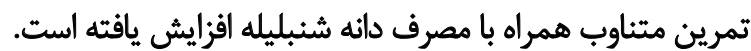

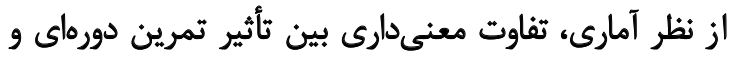

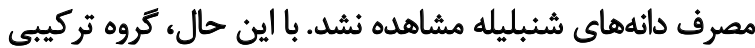

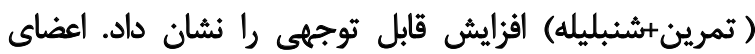

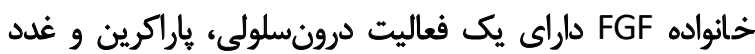

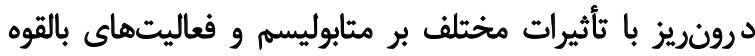
سيستم قلبى - عروقى هستئد.

شواهدى وجود داشته است كه اعضاى خانواده غدد درونزا با 
شود؛ بنابراين اين سازگًارى با تمرين و مصرف شنبليله مىتواند

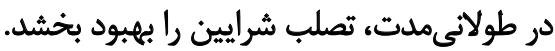

با اين حال، نياز به تحقيقات وسيعتر در اين مورد وجود دارد.

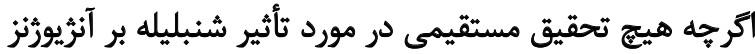

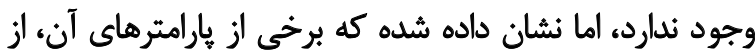

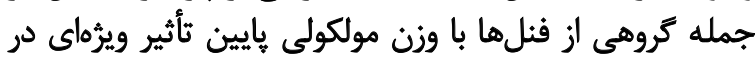
درمان بيمارىهاى قلبى دارند.

علاوه بر اين، مجموعهاى از تحقيقات به دليل توانايع فلاونوئيدها

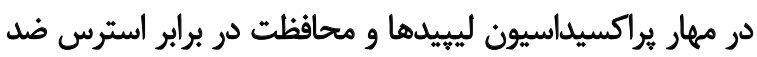

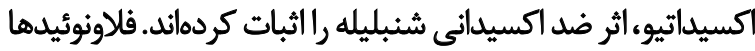

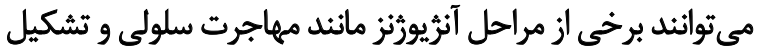

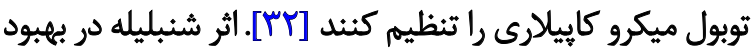

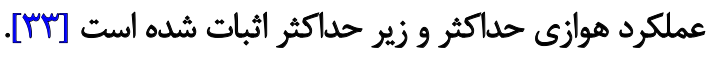
همجينين، مطالعات يادشده نشان دادند عصاره شنبليله به

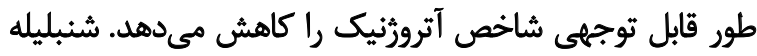

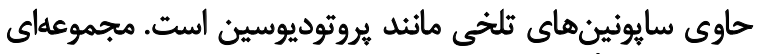

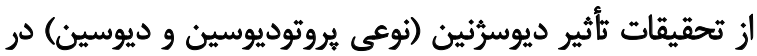

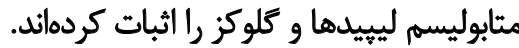

ديوسرثنين سطح كيرنده فعال كننده بروليفراسيون يروكسيزوم

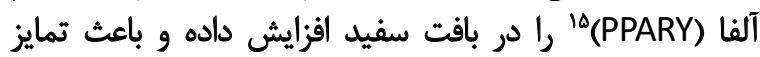

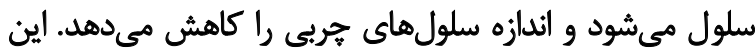

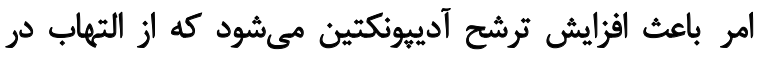

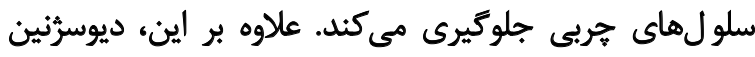

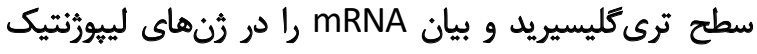

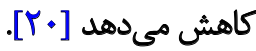

$$
\text { تئيجه كيرى }
$$

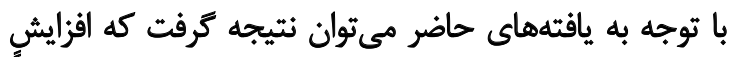

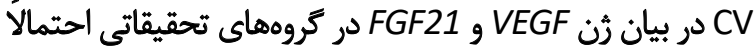

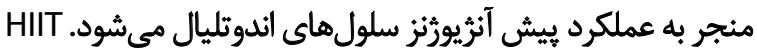

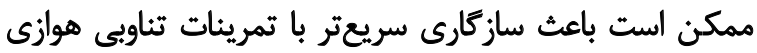

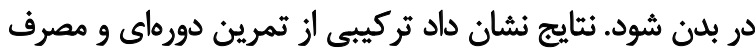

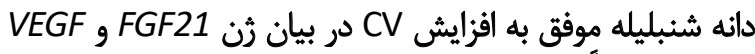

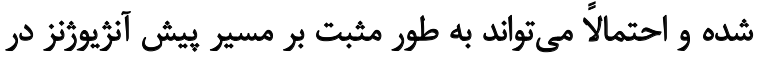

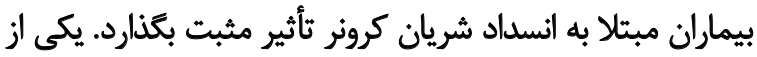

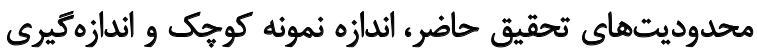

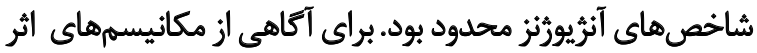

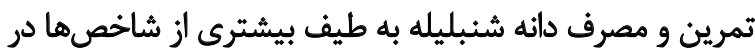
تحقيقاتنيازمنديم ملاحظات اخلاقي

15. Peroxisome proliferator-activated receptor $Y$
بيان و ترشح FGF21 با بيان بيش از حد Akt1 ثنظيم مىشود.

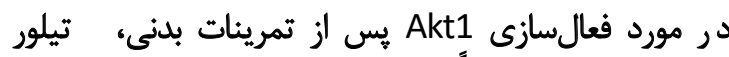

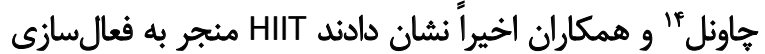

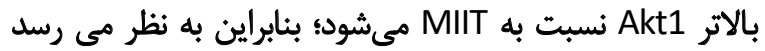

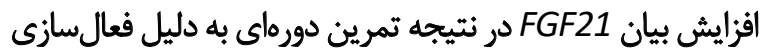

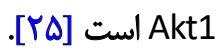

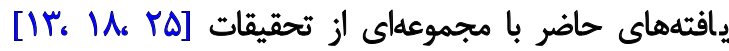

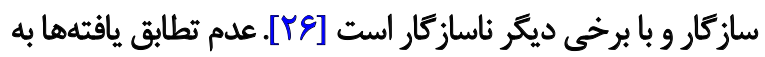

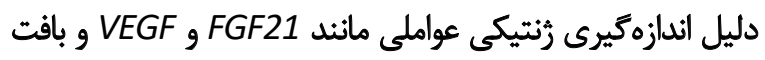

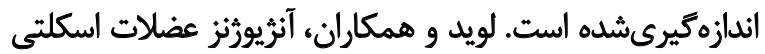

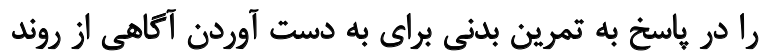

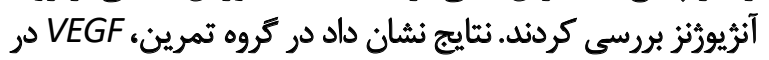

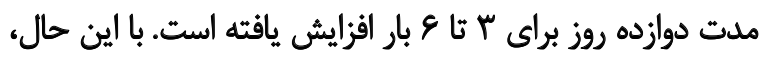

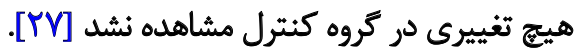

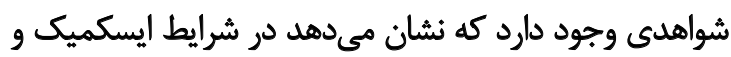

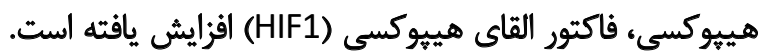

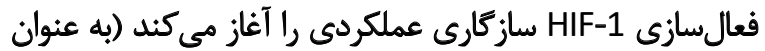

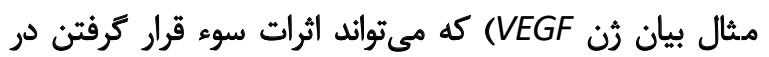
معرض هييوكسى راكاهش دهد.

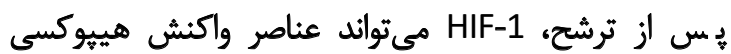

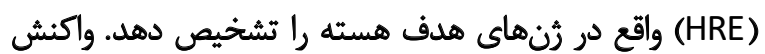

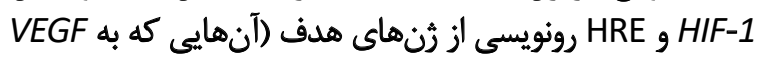

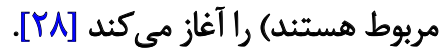
بلهوروكلى، همانطور كه يافتههاى حاضر نشان داد، احتمالاً

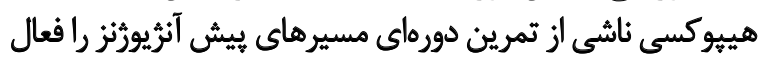

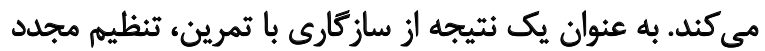

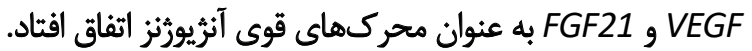

مجموعهاى از تحقيقات نشان دادند در بيماران قلبى، ايروبيك ائريك

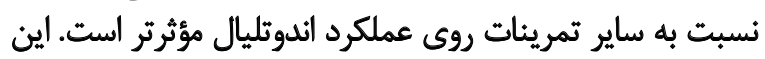

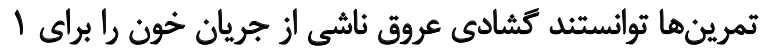

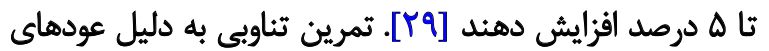

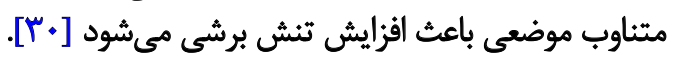
علاوه بر اين، طبق تحقيقات اخير، شنبليله به دليل اثرات آنيات

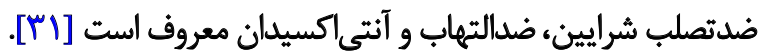

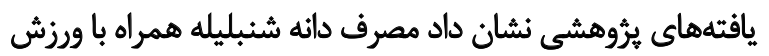

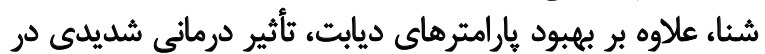

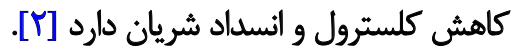

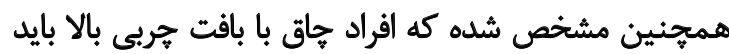

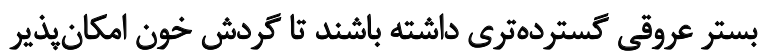




\section{بيروى أز أصول اخلاق يُوهش}

اين يرورةه تحقيقاتى توسط كميته اخلاق دانشكاه آزاد اسلامى تائي

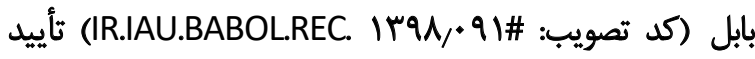
شده است.

$$
\text { مامي مالي }
$$

تمام نويسندكان در طراحى، اجرا و نكارش همه بخش دهاي ئروهش حاضر مشاركت داشتهاند.

$$
\text { مشاركت نويسند مكان }
$$

تمام نويسندكان در طراحى، اجرا و نكارش همه بخشهاى يُورهش حاضر مشاركت داشتهاند.

$$
\text { تارض مثأع }
$$

بنابر اظهار نويسندكان اين مقاله تعارض منافع ندارد. 


\section{References}

[1] Szabó K, Gesztelyi R, Lampé N, Kiss R, Remenyik J, Pesti-Asbóth G, et al. Fenugreek (Trigonella foenum-graecum) seed flour and diosgenin preserve endothelium-dependent arterial relaxation in a rat model of early-stage metabolic syndrome. International Journal of Molecular Sciences. 2018; 19(3):798. [DOI:10.3390/ijms19030798] [PMID] [PMCID]

[2] Arshadi S, Azarbayjani MA, Hajiaghaalipour F, Yusof A, Peeri M, Bakhtiyari $S$, et al. Evaluation of Trigonella foenum-graecum extract in combination with swimming exercise compared to glibenclamide consumption on type 2 Diabetic rodents. Food \& Nutrition Research. 2015; 59:29717. [DOI:10.3402/fnr.v59.29717] [PMID] [PMCID]

[3] Kruse R, Vienberg SG, Vind BF, Andersen B, Højlund K. Effects of insulin and exercise training on FGF21, its receptors and target genes in obesity and type 2 diabetes. Diabetologia. 2017; 60(10):2042-51. [DOI:10.1007/ s00125-017-4373-5] [PMID]

[4] Joo CH, Allan R, Drust B, Close GL, Jeong TS, Bartlett JD, et al. Passive and post-exercise cold-water immersion augments PGC-1 $\alpha$ and VEGF expression in human skeletal muscle. European Journal of Applied Physiology. 2016;116(11-12):2315-26. [DOI: 10.1007/s00421-016-3480-1]

[5] Morland C, Andersson KA, Haugen $\varnothing$ P, Hadzic A, Kleppa L, Gille A, et al. Exercise induces cerebral VEGF and angiogenesis via the lactate receptor HCAR1. Nature Communications. 2017; 8:15557. [DOI:10.1038/ ncomms15557] [PMID] [PMCID]

[6] Gibala MJ. [High-intensity interval training: New insights (Chinese)]. Chinese Sports Medicine. 2008; 3. https://www.cnki.com.cn/Article/ CJFDTotal-YDYX200803031.htm

[7] Myllyharju J, Koivunen P. Hypoxia-inducible factor prolyl 4-hydroxylases: Common and specific roles. Biological Chemistry. 2013; 394(4):435-48. [DOI:10.1515/hsz-2012-0328] [PMID]

[8] Rezaei R, Nourshahi M, Bigdeli MR, Khodagholi F, Haghparast A. [Effect of eight weeks continues and HIIT exercises on VEGF-A and VEGFR-2 levels in stratum, hippocampus and cortex of wistar rat brain (Persian)]. Physiology of Sport and Physical Activity. 2015; 8(2):1213-21. https:// www.sid.ir/en/journal/ViewPaper.aspx?id=604098

[9] Domouzoglou EM, Naka KK, Vlahos AP, Papafaklis MI, Michalis LK, Tsatsoulis A, et al. Fibroblast growth factors in cardiovascular disease: The emerging role of FGF21. American Journal of Physiology-Heart and Circulatory Physiology. 2015; 309(6):H1029-38. [DOI:10.1152/ajpheart.00527.2015] [PMID] [PMCID]

[10] Luo Y, McKeehan WL. Stressed Liver and Muscle Call on Adipocytes with FGF21. Frontiers in Endocrinology. 2013; 4:194. [DOI:10.3389/ fendo.2013.00194] [PMID] [PMCID]

[11] Iglesias P, Selgas R, Romero S, Díez JJ. Mechanisms In Endocrinology: Biological role, clinical significance,and therapeutic possibilities of the recently discovered metabolic hormone fibroblastic growth factor 21 . European Journal of Endocrinology. 2012; 167(3):301-9. [DOI:10.1530/ EJE-12-0357] [PMID]

[12] Poher AL, Altirriba J, Veyrat-Durebex C, Rohner-Jeanrenaud F. Brown adipose tissue activity as a target for the treatment of obesity/insulin resistance. Frontiers in Physiology. 2015; 6:4. [DOI:10.3389/ fphys.2015.00004] [PMID] [PMCID]

[13] Chau MD, Gao J, Yang Q, Wu Z, Gromada J. Fibroblast growth factor 21 regulates energy metabolism by acti-vating the AMPK-SIRT1-PGC1alpha pathway. Proceedings of the National Academy of Sciences of the United States of America. 2010; 107(28):12553-8. [DOI:10.1073/ pnas.1006962107] [PMID] [PMCID]
[14] Scalzo RL, Peltonen GL, Giordano GR, Binns SE, Klochak AL, Paris HL, et al. Regulators of human white adipose browning: Evidence for sympathetic control and sexual dimorphic responses to sprint interval training. PLoS One. 2014; 9(6):e90696. [DOI:10.1371/journal.pone.0090696] [PMID] [PMCID]

[15] Jeon JY, Choi SE, Ha ES, Kim TH, Jung JG, Han SJ, et al. Association between insulin resistance and impairment of FGF21 signal transduction in skeletal muscles. Endocrine. 2016; 53(1):97-106. [DOI:10.1007/ s12020-015-0845-x]

[16] Hansen JS, Pedersen BK, Xu G, Lehmann R, Weigert C, Plomgaard P. Exercise-induced secretion of FGF21 and follistatin are blocked by pancreatic clamp and impaired in type 2 diabetes. The Journal of Clinical Endocrinology and Metabolism. 2016; 101(7):2816-25. [DOI:10.1210/ jc.2016-1681] [PMID]

[17] Tanimura Y, Aoi W, Takanami Y, Kawai Y, Mizushima K, Naito Y, et al. Acute exercise increases fibroblast growth factor 21 in metabolic organs and circulation. Physiological Reports. 2016; 4(12):e12828. [DOI:10.14814/phy2.12828] [PMID] [PMCID]

[18] Barari A, Bashiri J, Sarabandi M. [The effect of circuit resistance training combined with ginseng supplementation level of VEGF and PDGF in inactive females (Persian)]. Medical Journal of Tabriz University of Medical Sciences and Health Services. 2015; 37(5):6-13. https://mj.tbzmed. ac.ir/Article/9821

[19] Heshmat-Ghahdarijani K, MashayekhiasI N, Amerizadeh A, Teimouri Jervekani Z, Sadeghi M. Effect of fenugreek consumption on serum lipid profile: A systematic review and meta-analysis. Phytotherapy research. 2020; 34(9):2230-45. [DOI:10.1002/ptr.6690]

[20] Yousefi E, Zavoshy R, Noroozi M, Jahani Hashemi H, Zareiy S, Alizadeh $\mathrm{K}$, et al. [Effect of oral administration of fenugreek seeds powdered on lipid profile (Persian)]. Ebnesina. 2015; 17(1):33-8. https://www.sid.ir/ en/Journal/ViewPaper.aspx?ID=482303

[21] Wani SA, Kumar P. Fenugreek: A review on its nutraceutical properties and utilization in various food products. Journal of the Saudi Society of Agricultural Sciences. 2018; 17(2):97-106. [DOI:10.1016/j.jssas.2016.01.007

[22] Naghibi S, Maleki J. [The effect of exercise training on anaerobic threshold and exercise tolerance in patients with coronary artery disease (Persian)]. Social Research. 2011; 4(11):17-33. https://www.sid.ir/ en/journal/ViewPaper.aspx?ID=259157

[23] Pereira JA, Oliveira I, Sousa A, Valentao P, Andrade PB, Ferreira ICFR et al. Walnut (Juglans regia) leaves: Phenolic compound, antibacterial activity and antioxidant potential of different cultivars. Food and Chemical Toxicology. 2007; 45(11):2287-95. [DOI:10.1016/j.fct.2007.06.004] [PMID]

[24] Subasi SS, Gelecek N, Ozdemir N, Ormen M. Influences of acute resistance and aerobic exercises on plasma homocysteine level and lipid profiles. Turkish Journal of Biochemistry-Turk Biyokimya Dergisi. 2009; 34(1):9-14. https://www.researchgate.net/publication/253019662 Influences_of_acute_resistance_and_aerobic_exercises_on_plasma_homocysteine_level_and_lipid_profiles

[25] Chavanelle V, Boisseau N, Otero YF, Combaret L, Dardevet D, Montaurier C, Delcros G, et al. Effects of high-intensity interval training and moderate-intensity continuous training on glycaemic control and skeletal muscle mitochondrial function in $\mathrm{db} / \mathrm{db}$ mice. Scientific Reports 2017; 7(1):1-0. [DOI:10.1038/s41598-017-00276-8] [PMID] [PMCID]

[26] Czarkowska-Paczek B, Zendzian-Piotrowska M, Bartlomiejczyk I, Przybylski J, Gorski J. The influence of physical exercise on the generation of TGF- $\beta 1$, PDGF-AA, and VEGF-A in adipose tissue. European Journal of Applied Physiology. 2011; 111(5):875-81. [DOI:10.1007/s00421-0101693-2] [PMID] [PMCID] 
[27] Lloyd PG, Prior BM, Li H, Yang HT, Terjung RL. VEGF receptor antagonism blocks arteriogenesis, but only partially inhibits angiogenesis, in skeletal muscle of exercise-trained rats. American Journal of PhysiologyHeart and Circulatory Physiology. 2005; 288(2):H759-68. [DOI:10.1152/ ajpheart.00786.2004] [PMID]

[28] Kordi MR, Nekouei A, Shafiee A, Hadidi V. [The effect of eight weeks high intensity aerobic continuous and interval training on gene expression of vascular endothelial growth factor in soleus muscle of healthy male rats (Persian)]. Arak Medical University Journal. 2015; 18(8):53-62. https://www.sid.ir/en/journal/ViewPaper.aspx?id=531101

[29] Ghardashi Afousi AR, Gaeini A, Gholami Borujeni B. [The effect of aerobic interval training on endothelial vasculature function in type 2 diabetes patient (Persian)]. Iranian Journal of Rehabilitation Research. 2016; 2(3):27-39. http://ijrn.ir/article-1-215-en.html

[30] Wisloff U, Stoylen A, Loennechen JP, Bruvold M, Haram PM, Tjonna $A E$, et al. Superior cardiovascular effect of aerobic interval-training versus moderate continuous training in elderly heart failure patients: 651May 31 8: 15 AM-8: 30 AM. Medicine \& Science in Sports \& Exercise. 2007; 39(5):S32. [DOI:10.1249/01.mss.0000273010.06226.99]

[31] Emtiazy M, Oveidzadeh L, Habibi M, Molaeipour L, Talei D, Jafari Z, et al. Investigating the effectiveness of the Trigonella foenum-graecum L.(fenugreek) seeds in mild asthma: A randomized controlled trial. Allergy, Asthma \& Clinical Immunology. 2018; 14:19. [DOI:10.1186/s13223018-0238-9] [PMID] [PMCID]

[32] Nisari M, Alpa S, Yilmaz S, Inanc N. Effects of fenugreek extract on total antioxidant/oxidant status at ehrlich ascites tumor bearing mice. European Journal of Management Issues. 2020; 4(1):116-22. [DOI:10.14744/ ejmi.2020.17680]

[33] Goh Zhong Sheng J. Effects of curcumin and fenugreek soluble fiber supplements on submaximal and maximal aerobic performance indices in untrained college-aged subjects [MSc. Thesis]. Kentucky: University of Kentucky; 2019. [DOI:10.13023/etd.2019.465.] 
This Page Intentionally Left Blank 